\title{
PSYCHE
}

VOL. XX.

OCTOBER, 1913.

No. 5

\section{THE GALL MIDGE FAUNA OF NEW ENGLAND.}

By E. P. Feut,

Albany, N. Y.

The following list of New England Diptera referable to the Itonididæ has been made possible through the co-operation of a few individuals. Mr. C. W. Johnson and Mr. Owen Bryant have collected in various localities and generously placed their material at our disposal, while Miss Cora H. Clarke has been particularly successful in collecting galls and rearing the adults. The late Dr. M. T. Thompson made noteworthy additions to our knowledge of this group. In addition to the above we have referred to the list of insect galls prepared by Miss Stebbins. ${ }^{1}$ This latter includes a considerable number of common species which have also been recorded or observed by other workers.

In view of the fact that nearly 900 species of gall midges are known to occur in America, it can hardly be claimed that the present list of 137 species exhausts the possibilities for New England, though it compares very favorably with the list of forms recorded by us from western North America, ${ }^{2}$ a territory much larger and more diversified than that of New England. The similarities and differences in our knowledge concerning the fauna of these areas is well shown in the following tabulation.

1 1910, Stebbins, F. A. Springfield Mus. Nat. Hist. Bul. 2.

2 1912, Pomona College Journ. of Ent. 4:753-57. 
AMERICAN SPECIES OF ITONIDIDE.

\begin{tabular}{|c|c|c|c|}
\hline Subfamilies or tribes & $\begin{array}{c}\text { North } \\
\text { America }\end{array}$ & New England & $\begin{array}{c}\text { Western } \\
\text { North America }\end{array}$ \\
\hline Lestremiinariæ. . . . . . & 29 & 3 & 9 \\
\hline Campylomyzariæ....... & 58 & 4 & 11 \\
\hline Heteropezinæ... . & 13 & 2 & 0 \\
\hline Epidosariæ. . & 70 & 6 & 4 \\
\hline Dasyneuriariæ. & 129 & 21 & 15 \\
\hline Lasiopterariæ. . . & 143 & 25 & 22 \\
\hline Oligotrophiariæ........ & 86 & 16 & 20 \\
\hline Asphondyliariæ........ & 67 & 16 & 21 \\
\hline \multirow[t]{2}{*}{ Itonidinariæ........... } & 278 & 44 & 20 \\
\hline & 873 & 137 & 122 \\
\hline
\end{tabular}

A reference to the above table shows a fairly uniform tribal and subfamily representation in the known New England forms. A detailed examination of the list will show that much of our knowledge of Cincticornia and Caryomyia is due to the work of Miss Clarke. Comparing the New England fauna with that of the western part of the Continent, it will be noted that in the latter, both the Lestremiinariæ and the Campylomyzariæ exceed the New England forms by considerable, while no representative of the Heteropezinæ has been collected and there is a relatively small representation of the Itonidinariæ. Over half of the known American species have been reared. There is still an immense amount of work to be done along this line and in New England at least, one would expect judicious collecting to result in the discovery of at least a fairly rich fauna in both the Heteropezinæ and the Epidosariæ.

A considerable porportion of the many forms occurring on Salix and Solidago ${ }^{3}$ should be found in New England.

In addition to the species tabulated below, there are some twenty-two names which have been applied to galls collected in New England and which probably represent undescribed forms. These latter names, some of which are valid, are given at the end of the list.

3 Journ. Econ. Entom. 4:468-72. 
LESTREMIIN Æ.

Lestremiinariæ.

Catocha americana Felt, Franconia, N. H., Mrs. A. T. Slosson.

C. slossonœ Felt, Franconia, N. H., Mrs. A. T. Slosson.

Lestremia franconice Felt, Franconia, N. H., Mrs. A. T. Slosson.

Campylomyzariæ.

Prionellus dilatata Felt, Worcester, Mass., Dr. M. T. Thompson.

Monardia barlowi Felt, Kingston, R. I., Prof. John Barlow.

M. articulosa Felt, White Mountains, Morrison.

M. modesta sp. nov., New Haven, Conn., H. L. Viereck.

Heteropezinæ.

Miastor americana Felt, Connecticut, Prof. W. M. Wheeler.

Johnsonomyia rubra Felt, Montpelier, Vt., C. W. Johnson, June 1906.

ITONIDIDINA

Epidosariæ.

Didactylomyia longimana Felt, Auburndale, Mass., August 1906, C. W. Johnson.

D. capitata sp. nov., North Adams, Mass., August 1907, Owen Bryant.

Colpodia cornuta sp. nov., Jamaica Plain, Mass., October 31, 1910, Miss Cora H. Clarke.

Dirhiza montana Felt, White Mountains, Morrison.

Asynapta frosti sp. nov., Framingham, Mass., June 1, 1910, C. A. Frost.

A. nobilis sp. nov., Bridgeton, Me., August 25, C. W. Johnson.

Dasyneuriariæ.

Rhabdophaga salicifolia Felt. Thickened, greenish midrib fold on Spiræa. Magnolia, Mass., Miss Cora H. Clarke.

$R$. batatas Walsh. Irregular, ovoid or subglobular twig gall on willow. Springfield, Mass., Miss F. A. Stebbins.

R. strobiloides Walsh. Pine cone gall on willow, common in New England.

$R$. brassicoides Walsh. Large, open, rosette or cabbage gall on willow. Springfield, Mass., Miss F. A. Stebbins.

$R$. gnaphaloides Walsh. Ovate, terminal bud gall on willow. Springfield, Mass., Miss F. A. Stebbins. 
Dasyneura trifolii Loew. Apposed, deformed, discolored leaflets of sweet clover. Stowe, Mass.

D. cyanococci Felt, Stowe, Mass., apical bud gall on blueberry.

D. clematidis Felt. Irregular, subglobular bud gall on Clematis. Springfield, Mass., Miss F. A. Stebbins.

D. parthenocissi Stebb. Thickened midrib or vein fold on Virginia creeper. Springfield, Mass., Miss F. A. Stebbins.

D. gleditschioe O. S., New Haven, Conn., on honey locust, June 1904, B. H. Walden.

D. americana nom. nov. (D. galii Felt) Magnolia, Mass. Flower bud galls on bedstraw, Miss Cora H. Clarke.

D. corticis Felt, Boston, Mass. Small willow twigs, Miss Cora H. Clarke.

D. seminivora Beutm. Irregular, deformed fruit of violet. Springfield, Mass., Miss F. A. Stebbins.

D. salicifolii Felt, Magnolia, Mass. Young terminal adherent willow leaves, Miss Cora H. Clarke.

D. ulmea Felt. Aborted elm buds, Jamaica Plain, Mass., J. G. Jack.

D. gaylussacii Felt. Oval, valved midrib gall on cranberry. Springfield, Mass., Miss F. A. Stebbins.

D. radifolii Felt, Magnolia, Mass. Oval galls on root leaves of Solidago, Miss Cora H. Clarke.

D. aromatica Felt, Barre, Mass. Sprigs of mint, Miss Cora H. Clarke.

D. toweri Felt, Magnolia, Mass. Enlarged flower buds of Hypericum mutilum, Miss Cora H. Clarke.

D. serrulato O. S. Apical bud gall on alder. Springfield, Mass., Miss F. A. Stebbins.

Cystiphora viburnifolia Felt, Magnolia, Mass. Blister leaf galls on hobblebush, Miss Cora H. Clarke.

\section{Lasiopterariæ.}

L. vitis O. S. Irregular, tumid, greenish or reddish leaf or tendril gall on grape. Springfield, Mass., Miss F. A. Stebbins.

L. corni Felt. Yellowish, purple-margined, blister gall on Cornus stolonifera. Springfield, Mass., Miss F. A. Stebbins.

L. clavula Beutm. Clavate apical twig gall on flowering dogwood. Springfield, Mass., Miss F. A. Stebbins. 
L. impatientifolia Felt. Tumid midrib fold on balsam or jewelweed. Springfield, Mass., Miss F. A. Stebbins.

L. querciperda Felt. Subcortical swellings on white oak twigs.

New Haven, Conn., A. B. Champlain.

L. farinosa Beutm. Warty, pruinose leaf gall on blackberry. Springfield, Mass., Miss F. A. Stebbins.

L. nodulosa Beutm. Irregular, subcortical stem gall on blackberry. Springfield, Mass., Miss F. A. Stebbins.

L. galeopsidis Felt., Boston, Mass. Irregular stem galls on hemp nettle, Miss Cora H. Clarke.

L. virginica Felt, Magnolia, Mass. Stem galls on Marsh St. Johnswort, Miss Cora H. Clarke.

L. convolvuli Felt. Fusiform stem gall on hedge bindweed. Springfield, Mass., Miss F. A. Stebbins.

L. cylindrigalloe Felt. Long, uniform stem swelling on solidago. Mount Tom, Mass., Dr. J. R. Gillett.

L. solidaginis O. S. (tumifica Beutm.) Irregular or eccentric stem gall on solidago. Worcester, Mass. Dr.M.T.Thompson.

L. clarkei Felt, Magnolia, Mass. Whitish, circular blister gall on Aster macrophyllus, Miss Cora H. Clarke.

L. spircefolia Felt. Yellowish brown, blister gall on Spirca salicifolia. Magnolia, Mass., Miss Cora H. Clarke.

Neolasioptera vitinea Felt, Worcester, Mass. An obpyriform conical, slightly curved petiole gall on grape, Dr. M. T. Thompson.

N. sambuci Felt, Worcester, Mass. Irregular stem gall on elder, Dr. M. T. Thompson.

$N$. perfoliata Felt, Worcester, Mass. Stem gall on boneset, Dr. M. T. Thompson.

N. ramuscula Beutm., Worcester, Mass. Fusiform stem gall on aster, Dr. M. T. Thompson.

Asteromyia vesiculosa Felt, Magnolia, Mass. Oval swellings in aster leaves, Mrs. H. M. Tower.

A. carbonifera Felt. Oval, black blister gall on Salix graminifolia, Springfield, Mass., Miss F. A. Stebbins.

A. dumose Felt, Annisquam, Cape Ann, Mass. Inconspicuous blister leaf gall on aster, Miss Cora H. Clarke.

A. asterifolice Beutm. Yellowish white, dark-margined blister leaf gall on aster. Springfield, Mass., Miss F. A. Stebbins. 
A. flavolunata Felt. Marginal stem, oval, yellowish blister gall on Solidago canadensis. Springfield, Mass., Miss F.A.Stebbins.

Clinorhyncha filicis Felt, Magnolia, Mass. Apparently reared from galls of Hormomyia verruca Walsh, Miss Cora H. Clarke. Camptoneuromyia rubifolia Felt, Magnolia, Mass. Marginal leaf galls on high blackberry, Miss Cora H. Clarke.

\section{Oligotrophiariæ.}

Phytophaga rigide O. S. Apical, fusiform, beaked gall on willow. Springfield, Mass., Miss F. A. Stebbins.

Janetiella asplenifolia Felt, Worcester, Mass. Fleshy leaf fold near midvein of sweet fern leaves, Dr. M. T. Thompson.

Rhopalomyia clarkei Felt, Tamworth, N. H. Small, fusiform gall on Solidago leaves, Miss Cora H. Clarke.

R. hirtipes O. S. Worcester and Springfield, Mass. Globose rootstalk and apical stem galls, Dr. M. T. Thompson and Miss F. A. Stebbins.

R. racemicola O. S. Springfield, Mass. Greenish or reddish, subglobular flower bud gall on solidago, Miss F. A. Stebbins.

R. solidaginis Loew., Springfield, Mass. Apical, globular, rosette gall on solidago, Miss F. A. Stebbins.

R. anthophila O. S. Green, densely, pubescent, cylindric flower gall on solidago. Springfield, Mass., Miss F. A. Stebbins.

R. lateriflori Felt. Axillary bud gall on Aster lateriflorus. Springfield, Mass., Miss F. A. Stebbins (gemmaria).

R. thompsoni Felt, Worcester, Mass. Globular or ovoid root stalk gall on Solidago, Dr. M. T. Thompson.

R. astericaulis Felt, Worcester, Mass. Oval twig gall on aster, Dr. M. T. Thompson.

R. pedicellata Felt. Green, red-marked, fusiform, stemmed leaf gall on narrow-leaved solidago. Springfield, Mass., Miss F. A. Stebbins (euthamioe).

R. bulbula Felt, Worcester, Mass. Small bulb-like galls on Solidago, Dr. M. T. Thompson.

R. castaneo Felt, Stowe, Mass. Leaf petiole of chestnut.

$\boldsymbol{R}$. ? strobiligemma Stebb. Apical or axillary, ovate bud gall on white heath aster. Springfield, Mass., Miss F. A. Stebbins.

Sackenomyia virburnifolia Felt, Magnolia, Mass. Purplish vein swellings on Viburnum, Miss Cora H. Clarke. 
S. packardi Felt, Canton, Mass. Swollen twigs of the long-leaved willow, Winthrop Packard.

Asphondyliariæ.

Asphondylia monacha O. S., Barre, Mass. Apparently unmodified Solidago florets, small, apical rosette galls and adherent leaves, Miss Cora H. Clarke.

A. thalictri Felt, Magnolia, Mass. Distorted seed capsules of Thalictrum, Miss Cora H. Clarke.

A. ? diervillo Felt. Distorted fruit of bush honeysuckle. Springfield, Mass., Miss F. A. Stebbins (inaequalis).

A. conspicua O. S. Irregular, subglobular apical gall on cone flower. Westville, Conn., Dr. W. E. Britton.

Schizomyia pomum Walsh \& Riley. Green or reddish, nut-like, polythalamous bud gall on grape. Springfield, Mass., Miss F. A. Stebbins.

S. coryloides Walsh \& Riley. Clustered, fusiform, woolly, pubescent bud gall on grape. Springfield, Mass., Miss F. A. Stebbins.

Cincticornia serrata Felt, Boston, Mass. Circular blister galls on scarlet oak, Miss Cora H. Clarke.

C. caryo Felt, Worcester, Mass. Probably reared from oak leaf gall by Dr. M. T. Thompson.

C. pustulata Felt, Magnolia, Mass. Pustulate swellings on leaves of black oak, Miss Cora H. Clarke.

C. simpla Felt, Magnolia, Mass. Oval, blister galls on oak leaves, Miss Cora H. Clarke.

C. podagro Felt, Magnolia, Mass. Narrow, fusiform vein swellings on black oak leaves, Miss Cora H. Clarke.

C. globosa Felt, Magnolia, Mass. Subhemispheric galls on black oak leaves, Miss Cora H. Clarke.

C. pilulo Walsh, Worcester, Mass. Reddish brown, thickwalled galls on oak leaves, Dr. M. T. Thompson.

C. sobrina Felt, Worcester, Mass. Reared by Dr. M. T. Thompson, probably from oak leaves.

C. connecta Felt, Westville, Conn., Dr. W. E. Britton.

C. pustuloides Beutm. Blister or pustule galls on scarlet and black oak leaves. Springfield, Mass., F. A. Stebbins. 
Itonidinariæ.

Contarinia spirœina Felt, Magnolia, Mass. Bud galls on Spiræa, Miss Cora H. Clarke.

C. pyrivora Riley, Meriden, Conn., Coe Brothers.

C. setigera Lintn., Lowell, Mass. Reared from melon tips.

C. virginianioe Felt. Swollen, deformed fruit of wild cherry. Stowe, Mass.

Thecodiplosis dulichii Felt, Magnolia, Mass. Fruit of Dulichium, Miss Cora H. Clarke.

T. liriodendri O. S., Boston, Mass. Ocellate leaf galls on tulip, Mr. J. G. Jack.

Dicrodiplosis fulva sp. nov., Jamaica Plain, Mass. Leaf galls on oak identified as those of Neuroterus umbilicatus, Miss Cora H. Clarke.

D. antennata Felt, Orono, Me. Larvæ preying on false maple scale, Phenaccocus acericola King, Dr. O. A. Johannsen.

D. helena Felt, Magnolia, Mass. Subglobular galls on poplar leaves, Miss Cora H. Clarke.

Youngomyia umbellicola $\mathbf{O}$. S. Swollen, unopened florets of elder. Springfield, Mass., Miss F. A. Stebbins.

Aphidoletes cucumeris Lintn., Lowell, Mass. Reared from liceinfested melon tips.

Lobodiplosis acerina Felt, Brookline, Mass. C. W. Johnson.

L. quercina Felt, North Adams, Mass., Owen Bryant.

L. speciosa sp. nov. North Adams, Mass., August 1907, Owen Bryant.

Coquillettomyia bryanti sp. nov., North Adams, Mass., August 1907, Owen Bryant.

C. dentata Felt, Greylock Mountain, Mass., August 1907, Owen Bryant.

Clinodiplosis caulicola Coq., Portsmouth, N. H. Stems of Iceland poppies, D. W. Coquillett.

Caryomyia arcuaria Felt. Smooth, thin-walled hickory leaf gall. Worcester, Mass., Dr. M. T. Thompson.

C. caryo O. S. Nearly smooth, thin-walled, yellowish green or brown, usually slightly nippled hickory leaf gall. Springfield, Mass., Miss F. A. Stebbins.

C. inanis Felt. Thin-walled hickory leaf gall with false chamber at the apex. Worcester, Mass., Dr. M. T. Thompson. 
C. persicoides Beutm. Thick-walled, globose hickory leaf gall with short, curly hairs. Springfield, Mass., Miss F. A. Stebbins.

C. holotricha O. S. Thin-walled, globose hickory leaf gall with rather long, rust-red hairs. Springfield, Mass., Miss F. A. Stebbins.

C. caryccola O. S. Conical hickory leaf gall with a long, slender apical process. Springfield, Mass., Miss F. A. Stebbins.

C. sanguinolenta O. S. Conical, short, thin-walled hickory leaf gall. Springfield, Mass., Miss F. A. Stebbins.

C. tubicola O.S. Cylindric or tubular hickory leaf gall. Worcester, Mass., Dr. M. T. Thompson.

C. thompsoni Felt, Worcester, Mass. Hickory leaf gall, Dr. M. T. Thompson.

Hormomyia shawi sp. nov., Hampton, N. H., S. A. Shaw.

H. canadensis Felt, Magnolia, Mass. Woolly, lipped gall on shadbush leaves, Miss Cora H. Clarke.

H. johnsoni Felt, Auburndale, Mass., C. W. Johnson.

H. clarkei Felt, Magnolia, Mass. Terminal bud gall on Spiræa, Miss Cora H. Clarke.

H. verruca Walsh, Magnolia, Mass. Subconic, clustered galls on willow leaves, Miss Cora H. Clarke.

H. cincta Felt, Hampton, N. H., S. A. Shaw.

H. modesta sp. nov., Auburndale, Mass., C. W. Johnson, New Haven, Conn., B. H. Walden.

H. pudica sp. nov., Hampton, N. H., S. A. Shaw.

Monarthropalpus buxi Lab., Kingston, R. I. Blister galls on Box leaves, Prof. E. A. Stene.

Hyperdiplosis bryanti sp. nov., North Adams, Mass., August 1907, Owen Bryant.

Parallelodiplosis spirce Felt, Magnolia, Mass. Marginal roll on leaves of Spiræa, Miss Cora H. Clarke.

P. cattleyœ Moll., South Natick, Mass. Roots of Cattleya, A. P. Morse.

P. clarkei Felt, Magnolia, Mass. Narrow apical bud galls, on Spiræa, Miss Cora H. Clarke.

Itonida canadensis Felt, Magnolia, Mass. Woolly, oval vein galls on shadbush leaves, Miss Cora H. Clarke.

I. spirœina Felt, Magnolia, Mass. Bud galls on Spiræa, Miss Cora H. Clarke. 
I. foliora Rssl. \& Hkr., Amherst, Mass. Marginal leaf roll on oak leaves.

I. reflexa sp. nov., Hampton, N. H., S. A. Shaw.

I. rigido Pack., Springfield, Mass., Miss F. A. Stebbins.

A number of galls from which adults have not been reared have been recorded from New England. These deformities have been described and named as follows: •

Cecidomyia bedeguar Walsh, celastri Stebb., citrina O. S., crotalarioe Stebb., eupatorifloree Beutm., impatientis O. S., lappa Stebb., majalis Bass., muscosa Stebb., niveipila O. S., ocellaris O. S., pellex O. S., poculum O. S., potentilloccaulis Stebb., pudibunda O. S., racemi Stebb., reniformis Stebb., serotinœ O. S., squamulicola Stebb., tuba Stebb., veno Stebb., and verrucicola O. S.

A number of unnamed galls undoubtedly exist in New England territory.

\section{Descriptions of New Species Listed Above.}

Monardia modesta sp. nov.

This small midge was taken by Mr. H. L. Viereck at New Haven, Conn., November 4, 1903 . It is closely allied to M. alexanderi Felt from which it may be separated by colorational characters, the more slender antennal segments and the equal third and fourth palpal segments.

Female. Length, $.75 \mathrm{~mm}$. Antennæ hardly extending to the base of the abdomen, thickly haired, fuscous yellowish; 12 segments, the fifth pyriform, with a length one-fourth greater than its diameter and a short, though distinct stem; terminal segment fused with the preceding. Palpi, the third and fourth segments equal. Body a nearly uniform brownish black. Legs mostly fuscous yellowish; claws slender, evenly curved, the pulvilli as long as the claws. Ovipositor lobes triarticulate, the basal segment irregular, trapezoidal, the second quadrate, with a length two and one-half times its width, the third narrowly oval, setose apically. Type: Cecid. 1468.

Asynapta nobilis sp. nov.

The female described below was received from Mr. C. W. Johnson of the Boston Society of Natural History and labeled Bridgeton, Me., August 25. It is easily destinguished from other species of this genus by the long stems of the flagellate antennal segments. 
Female. Length, $3.5 \mathrm{~mm}$. Antennæ ncarly as long as the body, sparsely haired, dark brown, the stems white; sixteen segments, the fifth with a stem three-fourths the length of the cylindric basal enlargement, which latter has a length twice its diameter and is ornamented with very irregular, reticulate, stout circumfili; terminal segment produced, with a length about four times its diameter, the distal fifth tapering. Palpi; first segment with a length four times its diameter, the second a little longer, broader, the third longer than the second, more slender, the fourth one-half longer than the third, slightly dilated. Mesonotum yellowish brown. Scutellum and postscutellum yellowish. Abdomen sparsely haired, yellowish red. Halteres and coxæ mostly fuscous yellowish, the legs mostly fuscous straw, except the two distal tarsal segments of the anterior and mid legs and the distal three of the posterior legs which are yellowish white; claws slender, strongly curved, unidentate, the pulvilli rudimentary. Ovipositor nearly as long as the body, the terminal lobes triarticulate, the basal subtriangular, the middle subquadrate, the terminal narrowly oval, sparsely haired. Type: Cecid. 1464.

Asynapta frosti sp. nov.

The female described below was received from Mr. C. W. Johnson of the Boston Society of Natural History and bore the following label "Found in jar of sumac twigs and bees nest, C. A. Frost, Framingham, Mass., VI-1, 10.” It is easily distinguished from all other known American females by the number of antennal segments. Since the abdomen was recurved dorsally, this species may possibly be referable to the genus Ruebsaamenia Kieff.

Female. Length, $1.5 \mathrm{~mm}$. Antennæ extending to the fourth abdominal segment, sparsely haired, dark brown; twenty-two subsessile, cylindric segments, the fifth with a length three-fourths greater than its diameter; terminal segment slightly produced. Palpi; first segment long, slender, second as long as the first, broader, the third fully one-half longer than the second, the fourth about one-half longer than the third, more slender. Mesonotum shining dark brown. Scutellum fuscous yellowish, postscutellum darker. Abdomen thickly haired, whitish yellow. Wings hyaline, costa light straw. Halteres pale straw basally, fuscous apically. Coxæ pale straw. Legs mostly dark straw, posterior tarsi light straw; claws moderately long, stout, unidentate, the pulvilli as long as the claws. Ovipositor long, slender, recurved dorsally, the terminal lobes slender, biarticulate, the basal segment with a length fully four times its width, the distal segment more slender, narrowly elliptical. Type: Cecid. 1424.

Lobodiplosis speciosa sp. nov.

This remarkable male was taken by Owen Bryant, August, 1907, at North Adams, Mass., and may be easily separated from its allies by the two subapical lobes on the basal clasp segment.

Male. Length, $1 \mathrm{~mm}$. Antennæ twice the length of the body, thickly haired, light brown; fourteen segments, the fifth having the basal portion of the stem with 
a length one-half greater than its diameter, the distal part with a length two and one-half times its diameter, the distal enlargement constricted at the basal third and with a length nearly twice its diameter; terminal segment, the basal stem with a length five times its diameter, the distal enlargement irregular, with a length three times its diameter and an irregular, fingerlike process equally long. Palpi; first segment irregularly subquadrate, the second nearly twice the length of the first, the third, one-third longer than the second, the fourth, one-half longer than the third, more slender. Mesonotum dark brown. Scutellum and postscutellum fuscous yellowish. Abdomen thickly haired, yellowish brown. Halteres and legs mostly pale straw, the distal tarsal segments somewhat darker; claws slender, evenly curved, anterior unidentate, the pulvilli rudimentary. Genitalia fuscous yellowish; basal clasp segment broad, with a broad subquadrate, subapical, glabrous lobe and apically a tapering, spined lobe; terminal clasp segment long, slender; dorsal plate short, broadly and triangularly emarginate, the lobes tapering to a narrowly rounded, setose apex; ventral plate narrow, long, broadly rounded and thickly setose apically; style long, tapering. Type: Cecid. 1454.

\section{Coquillettomyia bryanti sp. nov.}

The midge described below is easily separated from its allies by the broad, white annulations on the tarsi. It was taken by Owen Bryant, August, 1907, at North Adams, Mass.

Male. Length, $1.25 \mathrm{~mm}$. Antennæ probably twice the length of the body, sparsely haired, fuscous yellowish; fourteen segments, the fifth having the stems with a length three and one-half and four and one-half times their diameters, respectively; distal enlargement with a length twice the diameter and a marked constriction near the basal third. Palpi; the first segment with a length three times its diameter, the second a little longer, stouter, the third slightly longer than the second and the fourth, one-half longer than the third, somewhat dilated. Mesonotum reddish brown, the submedian lines, scutellum and postscutellum fuscous yellowish. Abdomen yellowish brown. Halteres yellowish. Legs mostly dark brown, the first tarsal segment and the base of the second, white, the latter and third and fourth broadly annulate with white apically, the fifth white; claws slender, strongly curved basally, the anterior unidentate, the pulvilli about half the length of the claws. Genitalia; basal clasp segment stout, with a short emarginate lobe basally, the margin heavily chitinized; terminal clasp segment slender; dorsal plate short, broad, broadly and slightly emarginate; ventral plate short, tapering, broadly emarginate. Harpes produced as free, strongly recurved, heavily chitinized processes.

Female. Length, $1.25 \mathrm{~mm}$. Antennæ about as long as the body, sparsely haired, fuscous yellowish; fourteen segments, the fifth with a stem about threefourths the length of the cylindric basal enlargement, which latter has a length two and one-half times its diameter; basal portion of the distal segment cylindric, with a length four times its diameter and apically with a process as long as the enlargement and distinctly swollen at the basal fourth. Mesonotum brownish red. Abdomen brownish yellow. Ovipositor short, the lobes irregularly ovate and thickly setose, other characters practically as in the male. Type: Cecid. 1452, 1453. 
Hormomyia shawi sp. nov.

This midge was received from C. W. Johnson of the Boston Society of Natural History and labeled: "VIII-20, 1909 Hampton, N. H., S. A. Shaw 1187." It is allied to H. consobrina Felt, from which it is easily separated by coloration and the extremely slender second palpal segment.

Male. Length, $3.5 \mathrm{~mm}$. Antennæ as long as the body, thickly haired, pale yellowish; 15 segments, the fifth having the stems with a length one-half and onefourth greater than their diameters, respectively. The distal enlargement subcylindric, with a length fully half greater than its diameter; terminal segment rudimentary, subglobose. Palpi; first segment stout, with a length about twice its width, the second extremely long and slender, it having a length more than 10 times its diameter. Mesonotum light yellowish orange, submedian lines indistinct. Scutellum and postscutellum yellowish orange. Abdomen thickly haired, pale yellowish, the basal segment and genitalia yellowish orange. Wings hyaline, costa light straw. Halteres yellowish basally, fuscous apically. Coxæ yellowish orange; legs a nearly uniform dark straw; claws slender, evenly curved, the pulvilli rudimentary. Genitalia; basal clasp segment narrowly oval; terminal clasp segment moderately short, stout; dorsal plate broad, roundly and triangularly emarginate, the lobes broadly and irregularly rounded; ventral plate long, broad, subtruneate, slightly emarginate, both sparsely setose. Type: Cecid. 1423.

\section{Hormomyia modesta sp. nov.}

This species was taken at Auburndale, Mass., May 22, by Mr. C. W. Johnson of Boston. It may be recognized by the dark brown abdomen and the fourteen cylindric antennal segments, the fifth with a length two and one-half times its diameter and with three circumfili.

Description. Female, Length, $4 \mathrm{~mm}$. Antennæ sparsely haired, fuscous yellowish; fourteen segments, the fifth cylindric, with a length two and one-half times its diameter; sparse whorls of stout setæ occur basally and at the distal third; there are low circumfili near the basal third, the middle and apically; terminal segment slightly produced, with a distinct knob apically. Palpi; first segment short, second with a length three times its diameter, the third a little longer than the second, tapering. Mesonotum smooth, reddish brown, the yellowish submedian lines narrow. Scutellum pale yellowish, postscutellum yellowish, dark brown basally. Abdomen a nearly uniform shining dark brown; ovipositor pale orange; venter concolorous. Wings hyaline. Halteres yellowish basally, fuscous apically. Coxæ, femora and tibiæ mostly a light fuscous yellowish, tarsi fuscous yellowish or dark brown; claws stout, evenly curved, the pulvilli about one-third the length of the claws. Ovipositor short, the lobes broad, tapering to a broadly rounded apex. Type: Cecid. 1346. 
Hormomyia pudica sp. nov.

The female described below was received through $\mathrm{Mr}$. C. W. Johnson of the Boston Society of Natural History and labeled June 13, 1907, Hampton, N. H., S. A. Shaw, 1124. It is easily separated from other females having more than eighteen antennal segments, by the three circumfili and the long, uniarticulate palp.

Female. Length, $5 \mathrm{~mm}$. Antennæ extending to the third abdominal segment, sparsely haired, fuscous yellowish, at least eighteen segments, the fifth with a stem about one-fourth the subcylindric basal enlargement, which latter has a length twice its diameter, is rather strongly constricted near the basal third and bears well developed circumfili basally, near the middle and apically. Palpi; the one long segment is distinctly swollen basally, the distal two-thirds being slender and the total length over one-half the width of the head. Mesonotum dark reddish brown. Scutellum and postscutellum fuscous yellowish. Abdomen mostly reddish brown. Halteres and legs mostly fuscous straw; claws long, evenly curved, the pulvilli about half the length of the claws. Ovipositor short, terminal lobes broadly oval, thickly setose, the ventral lobe roundly triangular. Type: Cecid. 1465.

\section{Hyperdiplosis bryanti sp. nov.}

This interesting male was taken by Owen Bryant, August, 1907 at North Adams, Mass.

Male. Length, $1 \mathrm{~mm}$. Antennæ probably one-half longer than the body, sparsely haired, light straw; fourteen segments, the fifth having the stems three and three and one-half times their diameters, the circumfili moderately short. Palpi; first segment rather long, irregular, the second broad, with a length thrice its diameter, the third a little longer and more slender than the second, the fourth nearly as long as the third, somewhat dilated. Mesonotum reddish brown. Scutellum and post scutellum yellowish brown. Abdomen dark brown, the genitalia yellowish. Halteres mostly whitish, slightly fuscous apically. The legs mostly straw colored; claws strongly bent at right angles, simple, the pulvilli a little shorter than the claws. Genitalia; basal and terminal clasp segments moderately long, rather slender; dorsal plate short, deeply emarginate, the lobes apparently narrowly rounded; ventral plate greatly produced, deeply and roundly emarginate-in this specimen, irregularly so; style moderately long, stout. Type: Cecid. 1428.

Itonida reflexa sp. nov.

The male described below was received from Mr. C. W. Johnson of the Boston Society of Natural History and labeled: "I. B. 16, 1906, Hampton, N. H., S. A. Shaw, 1143." This species is easily separated from the allied $I$. putrida Felt by the dark brown abdomen and the somewhat longer antennal stems.

Male. Length, $2 \mathrm{~mm}$. Antennæ as long as the body, thickly haired, dark brown; fourteen segments, the fifth having the stems with a length one and one- 
fourth and one and three-fourths their diameters, respectively. Distal enlargement subcylindric, with a length one-fourth greater than its diameter; terminal segment, distal enlargement somewhat produced, irregularly fusiform. Palpi; first segment short, with a length one-half greater than its diameter, the second nearly twice the length of the first, the third a little longer than the second and the fourth three-fourths longer than the third, somewhat dilated. Mesonotum slaty gray, the grayish submedian lines sparsely haired. Scutellum and postscutellum dark gray. Abdomen thickly haired, dark brown. Wings hyaline, costa light straw. Halteres yellowish basally, fuscous apically. Coxæ and femora mostly fuscous yellowish; tibiæ and tarsi mostly dark brown; claws moderately stout, strongly curved, the pulvilli shorter than the claws. Genitalia; dorsal plate deeply and triangularly divided, the lobes narrowly triangular; ventral plate broad, broadly and roundly emarginate. Type: Cecid. 1422.

\title{
A VERNAL BEE (COLLETES INAEQUALIS SAY).
}

\author{
By John H. Lovell, \\ Waldoboro, Maine.
}

In Mr. Frost's interesting note on Tricrania sanguinipennis Say, which was published in Psyche, December, 1912, the name of the bee near whose burrows the beetles were found is given (through an inadvertence on my part) as Colletes compactus $\mathrm{Cr}$., when it should be $C$. inøqualis Say. The two species, while bearing a general superficial resemblance, may be distinguished by the difference in the sculpturing of the enclosure on the metathorax or prepodeum; and by the fact that the former is an autumnal species and the latter a vernal species, some three months intervening between the disappearance of $C$. inoqualis and the appearance of C. compactus.

I have this season received both sexes from Mr. Frost, to whom I am indebted for the following notes. The bees were abundant, and had constructed numerous burrows near the base of a sloping embankment, about three feet high, sparsely covered with grass. There were also nests where the ground was level and free from vegetation. As the burrows appeared to be unlined and the soil was sandy it was impossible to follow the tunnels to a depth of more than three or four inches. This species of Colletes in New England is on the wing for about two months, and is most commonly taken on the aments of the willows. Mr. Frost captured 

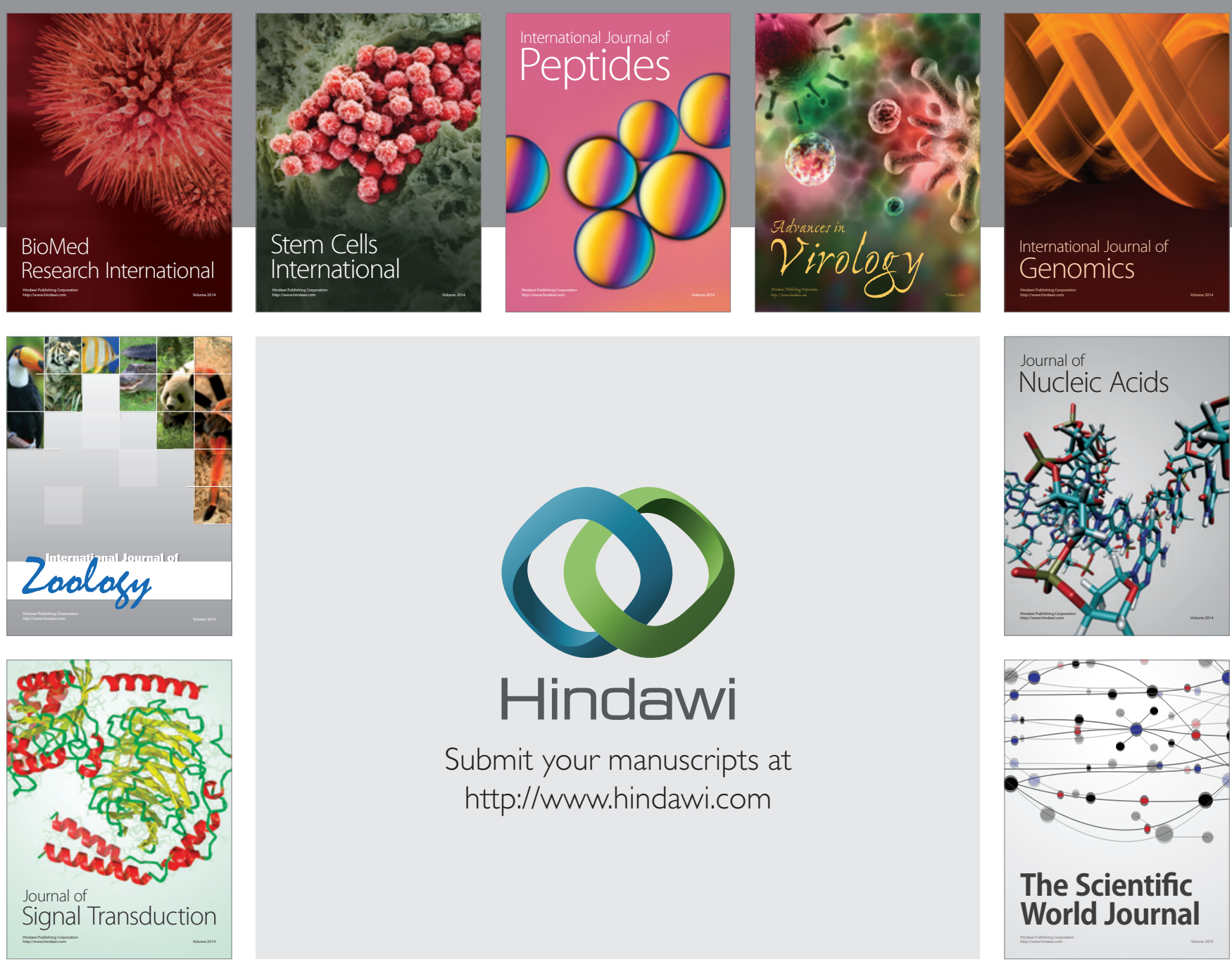

Submit your manuscripts at

http://www.hindawi.com
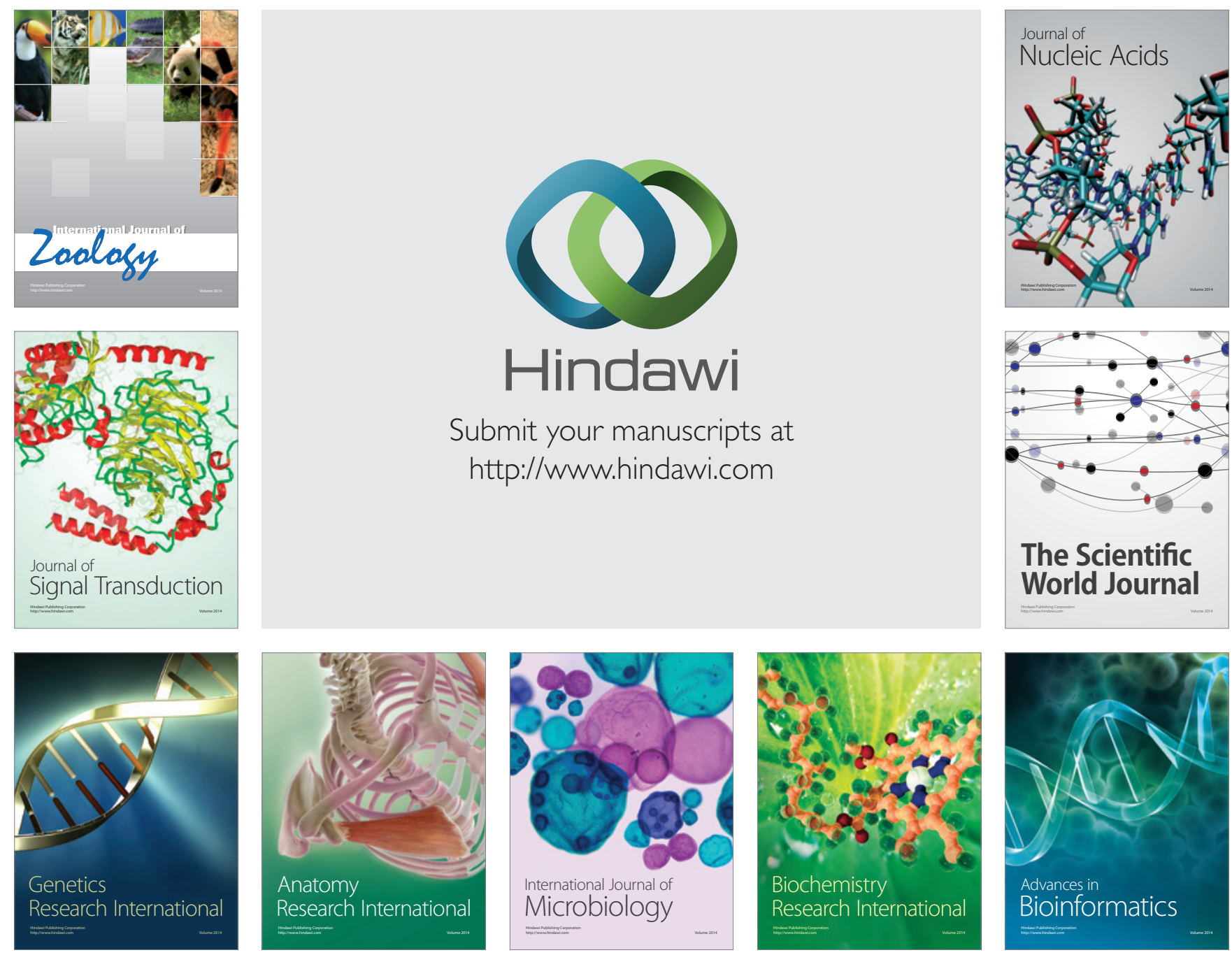

The Scientific World Journal
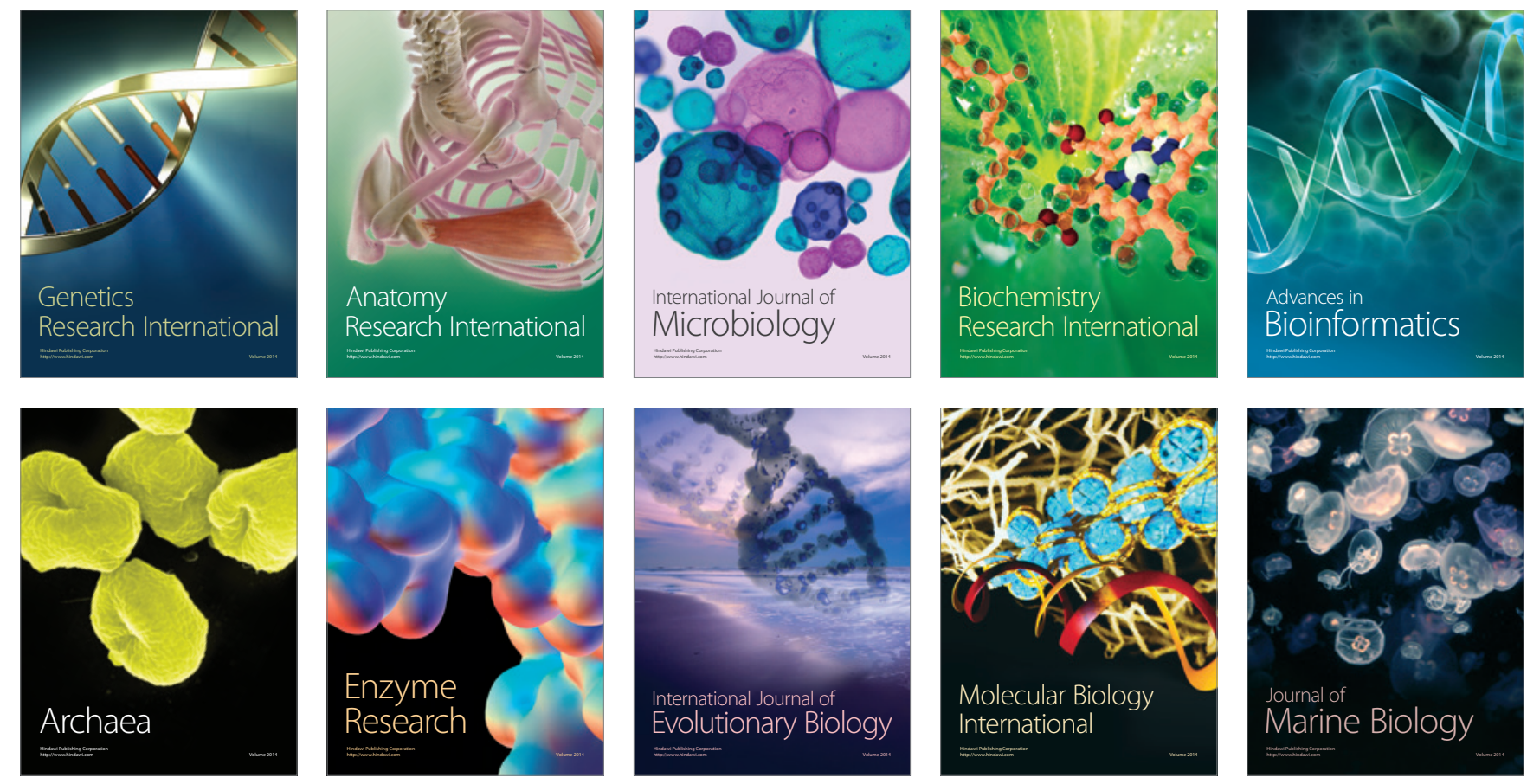